\title{
Spraying for Leaf Spot and Liming Increase Yam (Dioscorea Alata L.) Yield ${ }^{1,2}$
}

\author{
José Rodríguez-García, Fernando Abruña and Heber Irizarry ${ }^{3}$
}

\begin{abstract}
When yams were not sprayed to control leaf spot disease caused by Colletotrichum sp. essentially no yams were produced regardless of lime rates. When leaf spot was controlled by spraying, yam yields increased with increasing lime rates up to $36 \mathrm{t} / \mathrm{ha}$, the highest level tested. The combined effect of spraying and liming increased yields from 1.4 to $30.6 \mathrm{t} / \mathrm{ha}$. Yields were increased threefold when Al saturation of the soil exchange capacity was decreased from $37 \%$ to 0 by liming. Yields were decreased by $30 \%$ when Al saturation of the soil was increased only from 0 to $9 \%$, a level at which most crops will not show a response to Al. This decrease illustrates the extreme sensitivity of yams to exchangeable Al in the soil. Composition of the leaves 6 months after planting was affected neither by lime rates nor spraying. The $\mathrm{pH}, \mathrm{Al}$ saturation percentage of the soil exchangeable capacity, and lime rates applied were closely correlated with yam yields.
\end{abstract}

\section{INTRODUCTION}

Yams are an important source of carbohydrates in the diets of subsistence farmers throughout the tropics, but there is relatively little research information available on their culture. Most researchers have reported evaluations of varieties and planting systems $(2,3,5)$. There is little information on the effects of soil acidity on yam yields. Nye and Greenland (10) found a small response in yields of yams to liming after 8 years of continuously farming an Oxisol with an original $\mathrm{pH}$ of about $6.0 \mathrm{in}$ the savanna region of East Africa. Abruña et al. (1) found a strong response by yams to liming on Ultisols of Puerto Rico.

The leaf spot disease caused by Colletotrichum sp., generally described as "scorch" or "lightning," is a major limiting factor in yam production. The etiology of the disease has not been adequately determined, but its incidence has been associated with ecologic, physiologic, and soil factors. However, the International Institute of Tropical Agriculture at Ibadan, Nigeria (7) has been unable to correlate incidence of leaf spot disease with such factors as early appearance of necrosis, tuberization of the seed before planting, root necrosis, maturity of the tuber or natural and artificial shade. They found the species $D$. alata to be especially suscep-

${ }^{1}$ Manuscript submitted to Editorial Board August 24, 1982.

${ }^{2}$ This paper covers work carried out cooperatively between ARS-USDA and the Agricultural Experiment Station, College of Agricultural Sciences, Mayagüez Campus, University of Puerto Rico.

${ }^{3}$ Assistant Agronomist, Agricultural Experiment Station, College of Agricultural Sciences, Mayagüez Campus, University of Puerto Rico; and Soil Scientist and Research Horticulturist, ARS-USDA, respectively. 
tible to the disease, and benomyl applications at a 14-day interval over a period of 90 days did not reduce its prevalence or severity.

The present study evaluated the possible interaction between soil acidity factors and the spraying of a fungicide for control of leaf spot on yam yields.

\section{MATERIALS AND METHODS}

The work was carried out at the Corozal Substation on a moderately eroded Corozal clay (Aquic Tropudults) on a 10\% slope. A split-plot randomized block design was used with lime rates of $0,4.5,9.0,18.0$ and $36 \mathrm{t} / \mathrm{ha}$ applied as ground limestone and mixed with the upper $15 \mathrm{~cm}$ of soil as the main plots; spraying or no spraying treatments served as subplots, and all treatments were replicated five times. Main plots were $4.5 \times 8 \mathrm{~m}$ and subplots $4.5 \times 4 \mathrm{~m}$. All plots were surrounded by ditches to prevent runoff from one plot to another.

Tuber sections weighing around $200 \mathrm{~g}$ each of the yam cultivar Smooth Statia (Dioscorea alata L.) were planted $0.3 \mathrm{~m}$ apart in ridges $1.5 \mathrm{~m}$ apart. Wire trellises $2 \mathrm{~m}$ high were provided to support the vines. All plots received $500 \mathrm{~kg} / \mathrm{ha}$ of $10-10-10$ fertilizer containing $30 \mathrm{~kg} / \mathrm{t}$ of a mixture of $6 \% \mathrm{Mg}, 7.7 \% \mathrm{Mn}, 4.8 \% \mathrm{Cu}, 7 \% \mathrm{Fe}, 8 \% \mathrm{Zn}$, and $2.5 \% \mathrm{~B}$, at planting time and 5 mo later.

The fungicidal treatment was applied by a knapsack sprayer and consisted of spraying the foliage every 3 weeks with a solution containing $1 \mathrm{~kg}$ of benomyl (methyl 1-(butylcarbamoyl)-2-benzimidazolecarbamate) (Benlate $)^{4}$ in 400 liters of water. During spraying foliage in the untreated plots was protected with plastic sheeting.

We sampled the soil in all plots 4 months after liming by taking eight borings to a depth of $15 \mathrm{~cm}$. The samples were air dried and sieved through a 10-mesh screen. The samples were leached with normal neutral $\mathrm{NH}_{4} \mathrm{OAc}$ and $\mathrm{Ca}$ and $\mathrm{Mg}$ were determined by the Versenate method (4), $\mathrm{K}$ by flame photometry; and $\mathrm{Mn}$, colorimetrically as permanganate after oxidation with $\mathrm{KIO}_{4}$. Exchangeable $\mathrm{Al}$ was determined by extracting with $N \mathrm{KCl}$ and determining $\mathrm{Al}$ by the double titration method (9). Percent Al saturation of the soil was calculated considering the sum of exchangeable $\mathrm{Ca}, \mathrm{Mg}, \mathrm{K}, \mathrm{Al}$ and $\mathrm{K}$ as the effective cation exchange of the soil (6). Soil reaction was measured with a glass electrode $\mathrm{pH}$ meter with a 1:1.5 soil-water ratio.

The third and fourth leaves of plants growing in the center of each

\footnotetext{
${ }^{4}$ Trade names in this publication are used only to provide specific information. Mention of a trade name does not constitute a warranty of equipment or materials by the Agricultural Experiment Station of the University of Puerto Rico, nor is this mention a statement of preference over other equipment or materials.
} 
plot were taken as samples 6 months after planting; they were washed with distilled water, dried, and wet-digested with a mixture of $\mathrm{HNO}_{3}$ and $\mathrm{HClO}_{4}$. Phosphorus was determined colorimetrically (8), K by flame photometry, $\mathrm{Ca}$ and $\mathrm{Mg}$ by the Versenate method (4), and $\mathrm{Mn}$ colorimetrically after oxidation with $\mathrm{KIO}_{4}$.

Tubers were harvested 10 months after planting and yield of each plot was determined.

Analyses of variance were used to compare plot yields at the various lime levels with and without spraying. Yield and foliar analysis data were correlated to soil acidity factors through regression analyses.

TABLE 1.-Effect of five lime rates on yields and foliar composition of yams. (Dioscorea alata $L$.) with and without spraying with fungicide to control leaf spot disease in Puerto Rico

\begin{tabular}{|c|c|c|c|c|c|c|c|}
\hline \multirow{2}{*}{ Lime rate } & \multirow{2}{*}{$\begin{array}{c}\text { Yields } \\
\text { of } \\
\text { marketable } \\
\text { tubers }\end{array}$} & \multicolumn{6}{|c|}{ Foliar composition } \\
\hline & & $\mathrm{N}$ & $\mathrm{P}$ & $\mathrm{K}$ & $\mathrm{Ca}$ & $\mathrm{Mg}$ & $\mathrm{Mn}$ \\
\hline t/ha & t/ha & & & $\%$ & & . & \\
\hline \multicolumn{8}{|c|}{ Sprayed } \\
\hline 0 & $13.8 c^{1}$ & 2.37 & .11 & 2.63 & 1.90 & .27 & 136 \\
\hline 4.5 & $18.1 \mathrm{bc}$ & 2.74 & .10 & 2.64 & 1.90 & .30 & 150 \\
\hline 9.0 & $21.2 \mathrm{bc}$ & 2.68 & .13 & 2.84 & 2.00 & .33 & 142 \\
\hline 18.0 & $27.2 \mathrm{ab}$ & 2.66 & .12 & 2.94 & 1.81 & .32 & 109 \\
\hline 36.0 & $30.6 \mathrm{a}$ & 2.73 & .12 & 2.87 & 1.89 & .39 & 26 \\
\hline \multicolumn{8}{|c|}{ Not sprayed } \\
\hline 0 & $1.4 \mathrm{a}$ & 2.57 & .10 & 2.57 & 1.49 & .36 & 129 \\
\hline 4.5 & $1.8 \mathrm{a}$ & 2.58 & .09 & 2.69 & 1.48 & .27 & 69 \\
\hline 9.0 & $2.9 \mathrm{a}$ & 2.78 & .12 & 2.97 & 1.66 & .27 & 116 \\
\hline 18.0 & $3.2 \mathrm{a}$ & 2.80 & .12 & 2.90 & 1.70 & .25 & 72 \\
\hline 36.0 & $5.4 \mathrm{a}$ & 2.92 & .12 & 3.00 & 1.75 & .33 & 87 \\
\hline
\end{tabular}

${ }^{1}$ Means in columns for sprayed or for unsprayed plots followed by a letter in common do not differ significantly at the $5 \%$ probability level according to Duncan's multiple range test.

\section{RESULTS AND DISCUSSION}

Yields of yams increased with increasing lime levels from 13.8 up to $30.6 \mathrm{t} / \mathrm{ha}$ (table 1) when the plants were sprayed periodically for the control of the leaf spot disease. Without spraying, yields were almost nil but tended to increase with lime rates.

When no lime was applied, the unsprayed plants produced only $10 \%$ as much as the sprayed plants, and at the $36 \mathrm{t} / \mathrm{ha}$ lime rate the unsprayed plants yielded only $18 \%$ as much as those sprayed. The combined effect of spraying and liming increased marketable yields from 1.4 to $30.6 \mathrm{t} / \mathrm{ha}$ (table 1). 
Composition of the leaves sampled 6 months after planting was not affected by lime rates or spraying, and there was no significant interaction between lime rates and spraying (table 1).

Because of high variations in soil acidity levels among plots receiving the same lime rate, plots were grouped into categories according to the percentage of the soil exchange-complex saturated with $\mathrm{Al}$. Table 2 shows that yields dropped as the Al saturation of the soil increased from 0 up to $37 \%$ of the soil's cation exchange capacity. At this level of soil acidity yams produced only $34 \%$ of the yield obtained when there was no

TABLE 2.-Effect of soil acidity on yields and foliar composition of yams (Dioscorea alata L.) grown on an Ultisol and sprayed with fungicide to control leaf spot disease in Puerto Rico

\begin{tabular}{|c|c|c|c|c|c|c|c|c|}
\hline \multicolumn{2}{|c|}{ Soil acidity factors } & \multirow[b]{2}{*}{$\begin{array}{c}\text { Yields } \\
\text { of } \\
\text { marketable } \\
\text { tubers }\end{array}$} & \multicolumn{6}{|c|}{ Foliar composition } \\
\hline $\mathrm{pH}$ & $\begin{array}{l}\text { Saturation } \\
\text { with } \\
\text { exchan- } \\
\text { geable Al }\end{array}$ & & $\mathrm{N}$ & $\mathrm{P}$ & $\mathrm{K}$ & $\mathrm{Ca}$ & $\mathrm{Mg}$ & $\mathrm{Mn}$ \\
\hline & $\%$ & t/ha & & & $\%$ & & & $p / m$ \\
\hline 6.2 & 0 & 26.1 & 2.68 & .12 & 3.07 & 1.82 & .38 & 164 \\
\hline 4.8 & 9 & 18.4 & 2.63 & .12 & 2.56 & 1.82 & .36 & 187 \\
\hline 4.7 & 17 & 17.2 & 2.91 & .12 & 2.69 & 1.92 & .34 & 180 \\
\hline 4.6 & 25 & 13.7 & 2.73 & .10 & 2.59 & 1.81 & .32 & 115 \\
\hline 4.5 & 37 & 8.5 & 2.15 & .10 & 2.75 & 1.60 & .22 & 130 \\
\hline
\end{tabular}

TABLE 3.-Relationship between liming and soil acidity factors and yields of yams (Dioscorea alata)

\begin{tabular}{|c|c|c|}
\hline \multirow{2}{*}{$\begin{array}{l}\text { Soil acidity } \\
\text { factors } \\
\text { and liming }\end{array}$} & \multicolumn{2}{|c|}{ Marketable yield (t/ha) } \\
\hline & $\begin{array}{c}\text { Plants sprayed to control leaf spot dis- } \\
\text { ease }\end{array}$ & No spray applied \\
\hline $\mathrm{pH}$ & $\begin{array}{l}\mathrm{Y}=417.06+157.25 \mathrm{X}-13.83 \mathrm{X}^{2} \\
\quad r=.99^{* *}\end{array}$ & $\begin{array}{l}\mathrm{Y}=-38.75+13.47 \mathrm{X}-1.06 \mathrm{X}^{2} \\
\quad r=.98^{* *}\end{array}$ \\
\hline $\begin{array}{c}\text { Percent } \mathrm{Al} \\
\text { saturation }\end{array}$ & $\mathrm{Y}=24.58-.44 \mathrm{X} r=.98^{* *}$ & $\mathrm{Y}=3.65-.19 \mathrm{X}+.003 \mathrm{X}^{2} r=.92^{*}$ \\
\hline Lime rates & $\mathrm{Y}=13.74+.99 \mathrm{X}-.014 \mathrm{X}^{2} r=.99^{* *}$ & $\mathrm{Y}=1.10-.006 \mathrm{X}+.0027 \mathrm{X}^{2} r=.96^{* *}$ \\
\hline
\end{tabular}

exchangeable $\mathrm{Al}$ in the soil. There was a $30 \%$ reduction in yam yields when the Al saturation of the soil was increased from 0 to only $9 \%$, a level at which most crops would not show a response to Al. This response illustrates the extreme sensitivity of this variety of yams to exchangeable $\mathrm{Al}$ in the soil.

Chemical composition of the leaves was not significantly affected by soil acidity factors (table 2), although $\mathrm{N}, \mathrm{Ca}$ and $\mathrm{Mg}$ decreased at the highest level of acidity.

Regression analysis of the data (table 3 and figures 1 and 2) show that 
$\mathrm{pH}$, percent $\mathrm{Al}$ saturation of the soil's exchange capacity, and lime rates applied were closely correlated with yam yields with or without spraying to control leaf spot disease.

The data presented clearly show that the two main factors limiting increased yam production in Puerto Rico are leaf spot disease and high levels of acidity in the Ultisols where yams are usually grown. Yams are

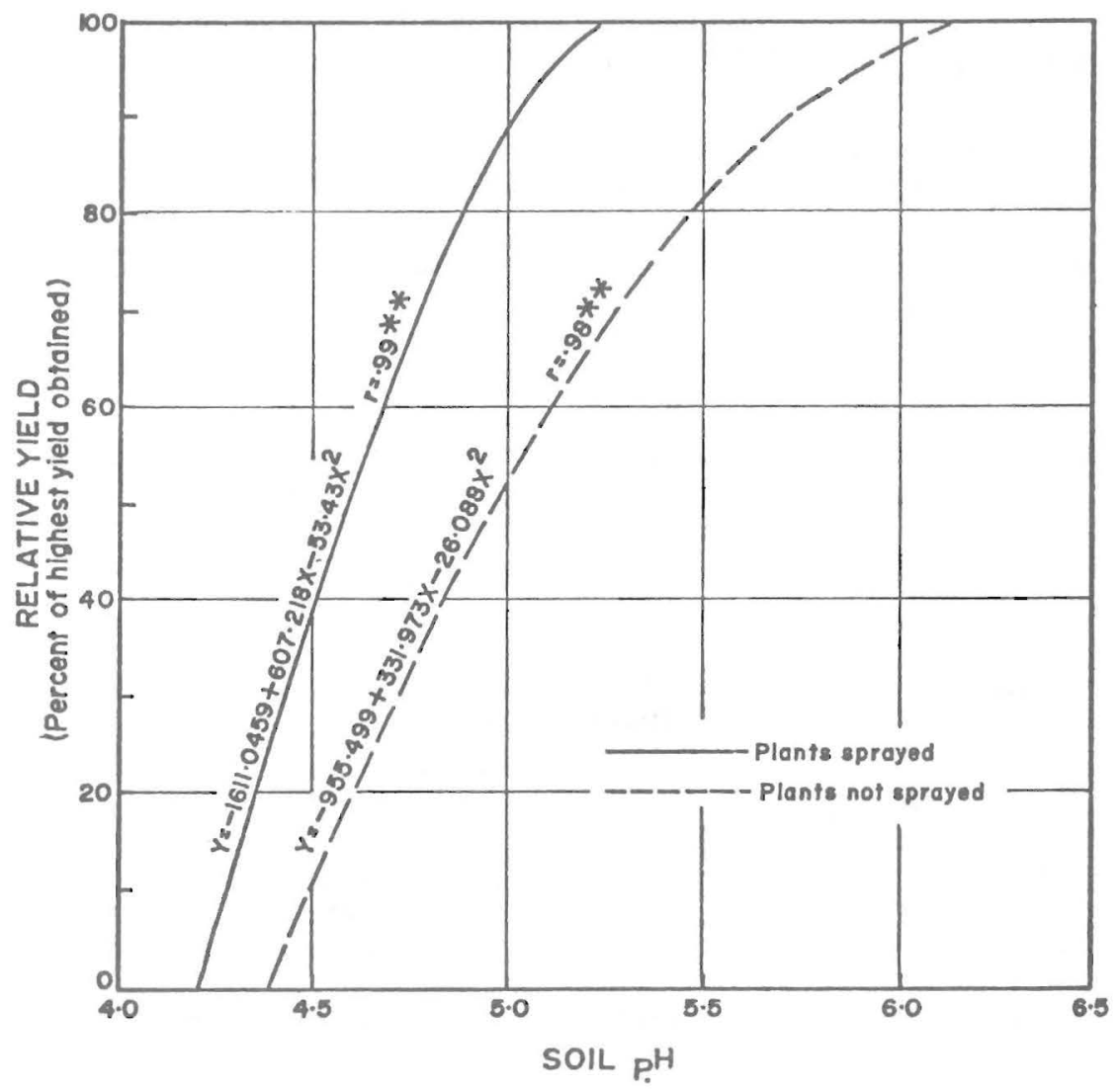

FIG. 1.-Relationship between soil $\mathrm{pH}$ and relative yield of yams in Puerto Rico with and without spraying with fungicide to control leaf spot disease caused by Colletotrichum sp.

extremely sensitive even to low exchangeable Al content in the soil. The species studied ( $D$. alata) is known for its sensitivity to leaf spot disease, yet it produced high yields of edible carbohydrates when sprayed periodically. Liming had no effect in ameliorating the damage caused by leaf spot disease. 
In order to produce yams profitably in Puerto Rico the soil must be limed to precipitate essentially all the exchangeable Al, and the foliage of the plants should be sprayed with an appropriate fungicide.

\section{RESUMEN}

El efecto de las aplicaciones de cal y de las aspersiones con fungicidas para controlar la mancha de la hoja o "candelilla" en la producción de

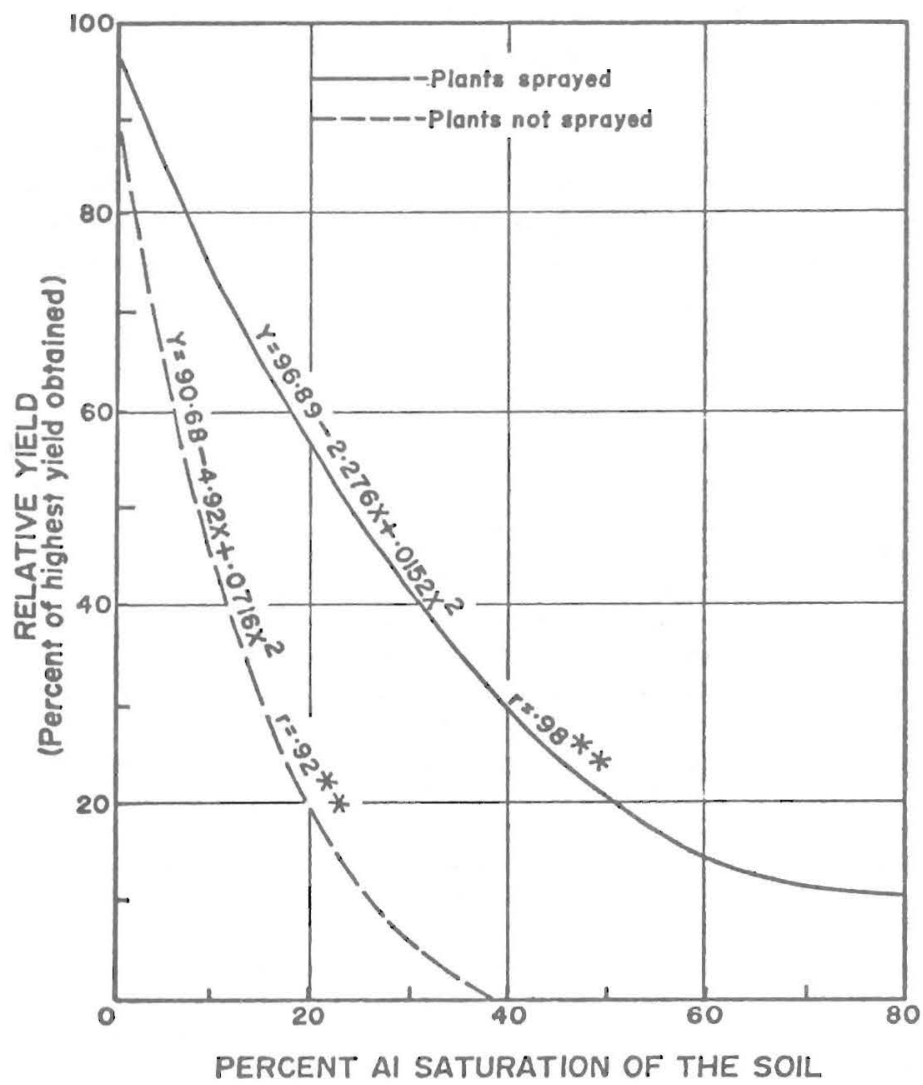

FIG. 2,-Relationship between soil percent Al saturation of the soil and yield of yams in Puerto Rico with and without spraying with fungicide to control leaf spot disease caused by Colletotrichum sp.

ñames se determinó con la variedad Smooth Statia (Dioscorea alata).

Apenas se cosecharon ñames comerciales cuando no se asperjó para controlar la candelilla.

Cuando se asperjaron, las plantas respondieron en producción a incrementos de piedra caliza molida hasta $36 \mathrm{Tm} / \mathrm{ha}$. La combinación de 
aspersión para el control de la candelilla y el encalado aumentaron el rendimiento de ñames de 1.4 a $30.6 \mathrm{Tm} / \mathrm{ha}$.

Hubo una relación directa entre el contenido de Al cambiable en el suelo y la producción de ñames. El rendimiento disminuyó en un 30\% cuando el nivel de $\mathrm{Al}$ en el suelo se aumentó al $9 \%$ de las bases cambiables, nivel que rara vez afecta la producción de otras cosechas, lo cual ilustra la sensitividad del ñame al Al en el suelo.

Hubo correlaciones altamente significativas entre el rendimiento de ñame con el nivel de cal aplicada, el pH del suelo y el contenido de Al cambiable en el suelo.

El contenido de distintos nutrimentos en las hojas no se afectó por cambios en los niveles del encalado ni por las aspersiones fungicidas.

Estos datos demuestran que los dos factores más limitativos en la producción del ñame en Puerto Rico son la candelilla y los altos niveles de acidez de los Ultisol, donde usualmente se siembra en Puerto Rico.

\section{LITERATURE CITED}

1. Abruña-Rodríguez, F., Vicente-Chandler, J., Rivera, E. and Rodríguez, J., 1982. Effect of soil acidity on yields and foliar composition of tropical root crops. Soil Sci. Soc. Am. J. 46 (5): 1004-9.

2. Campbell, J. S. and Gooding, H. J., 1962. Recent development in the production of food crops in Trinidad, Trop. Agric. (Trinidad) 39 (4): 261-68.

3. Caro-Costas, R., Boneta, E. and Silva, S., 1968. Effect of various cultural practices on yields of yams in Puerto Rico. J. Agric. Univ. P. R. 52 (4): 356-61.

4. Chang, K. L. and Bray, R. H., 1951. Determination of calcium and magnesium in soil and plant materials, Soil Sci. 72:449-58.

5. Chapman, T., 1965. Some investigations into factors limiting yields of the White Lisbon yam (Dioscorea alata L.) under Trinidad conditions, Trop. Agric. (Trinidad) 42 (2): 143-51.

6. Coleman, N. T., Weed, S. B. and McCraken, R. J., 1959. Cation-exchange capacity and exchangeable cations in Piedmont soils of North Carolina, Soil Sci. Soc. Am. Proc. $23: 146-49$.

7. International Institute of Tropical Agriculture, 1980 Annual Report, Ibadan, Nigeria, pp. 66-70.

8. John, M. K., 1970. Colorimetric determination of phosphorus in soil and plant materials with ascorbic acid, Soil Sci. 109 (4): 214-20.

9. McLean, E. O., 1965. Aluminum. In: Methods of Soil Analysis, Am. Soc. Agron. Series (Part 2) 9:994-96.

10. Nye, P. H. and Greenland, D. J., 1960. The soils under shifting cultivation, Commonwealth Bur. Soils, Tech. Comm. 51. 